Jacek Kulicki*

\title{
Władztwo podatkowe państwa i samorządu terytorialnego w zakresie podatków dochodowych - model scentralizowany czy zdecentralizowany?
}

\begin{abstract}
State tax authority and income tax collection. A centralized or decentralized model?: The paper overviews the division of competences between the central government and local government units regarding tax authority in the field of income taxation of natural and legal persons. The author looks at the following issues: income taxes as a source of own revenue of local government units, division of tasks and competences in the field of establishing rules regarding income tax, entitlement of local government units to their rates and collection. In the last section of the paper he presents conclusions and recommendations on the division of tasks and competences between the central government and local government units regarding the income tax collection.
\end{abstract}

\section{Słowa kluczowe: podatek dochodowy od osób fizycznych · podatek dochodowy od osób prawnych · jednostki samorządu terytorialnego · władztwo podatkowe \\ Keywords: personal income tax $\cdot$ corporate income tax $\cdot$ local government units $\cdot$ tax authority}

* Doktor nauk prawnych, ekspert ds. finansów publicznych BAS; e-mail: jacek.kulicki@sejm.gov.pl.

\section{Wstęp}

Przedmiotem artykułu jest obowiązujący i możliwy podział kompetencji dotyczący władztwa podatkowego w zakresie opodatkowania dochodów (przychodów) osób fizycznych i prawnych między państwo i jednostki samorządu terytorialnego (dalej również j.s.t.).

Pod pojęciem władztwa podatkowego państwa rozumiem uprawnienia do:

1 Szerzej zob. J. Kulicki, Zakres władztwa podatkowego w obecnym systemie prawnym w Polsce, seria „Analizy BAS” nr 16(41), 2010, http://www.bas.sejm.gov.pl/analizy.php. Zob. 
- stanowienia podatków, które obejmuje uprawnienia państwa do kształtowania jego polityki podatkowej oraz legislację podatkową, której zadaniem jest ujęcie $\mathrm{w}$ ramy prawne założeń polityki podatkowej zawartych w strategii podatkowej państwa,

- kształtowania (modelowania) przez jednostki samorządu terytorialnego, w ramach umocowania ustawowego, elementów wpływających na wysokość zobowiązania podatkowego podatnika, np. przez rozszerzenie ustawowego katalogu ulg bądź zwolnień podatkowych lub różnicowanie stawek podatkowych,

- poboru podatków, obejmujące swym zakresem wykonywanie prawa podatkowego przez organy skarbowe, a więc realizację funkcji rejestracyjnej, wymiarowej, weryfikacyjnej, kontrolnej, poboru i windykacji zobowiązań podatkowych,

- przeciwdziałania przestępczości skarbowej (podatkowej),

- dysponowania wpływami z podatków i innych danin publicznych.

Analizą objęto przede wszystkim trzy pierwsze grupy zagadnień, aczkolwiek rozważania na te tematy nie mogą abstrahować od pozostałych uprawnień państwa składających się na jego władztwo podatkowe. Dotyczy to w jednakowym stopniu przeciwdziałania przestępczości skarbowej, jak i dysponowania wpływami z podatków. Żaden z elementów władztwa podatkowego państwa nie może być bowiem traktowany odrębnie od pozostałych.

Rozważania dotyczą jedynie podatków dochodowych: od osób fizycznych, regulowane ustawą z 26 lipca 1991 r. o podatku dochodowym od osób fizycznych, t.j. Dz.U. 2018, poz. 200, ze zm. (dalej: u.p.d.f.), ustawą z 20 listopada 1998 r. o zryczałtowanym podatku dochodowym od niektórych przychodów osiąganych przez osoby fizyczne, t.j. Dz.U. 2017, poz. 2157, ze zm. (dalej: u.rycz.), oraz od osób prawnych, regulowany ustawą z 15 lutego 1992 r. o podatku dochodowym od osób prawnych, t.j. 2018, poz. 1036, ze zm. Stanowią one zasadniczą część dochodów własnych jednostek samorządu terytorialnego, a tym samym w istotny sposób wpływają na możliwości finansowania przez gminy, powiaty i województwa zadań własnych tych jednostek.

Poza zakresem analizy pozostawiono podatek tonażowy, regulowany ustawą z 24 sierpnia 2006 r. o podatku tonażowym, t.j. Dz.U. 2018, poz. 381., oraz zryczałtowany podatek od wartości budowy lub przebudowy statku, regulowany ustawą z 6 lipca 2016 r. o aktywizacji przemysłu okrętowego i przemysłów

również: A. Bień-Kacała, Zasada władztwa daninowego w Konstytucji RP z 1997 r., Dom Organizatora, Torun 2005; T. Dębowska-Romanowska, Istota i treść władztwa finansowego - samowola finansowa (samowola podatkowa) - zagadnienia pojęciowe [w:] Konstytucja, ustrój i system finansowy państwa. Księga pamiątkowa ku czci prof. Natalii Gajl, Warszawa 1999, s. 345-360; C. Kosikowski, Ustawa podatkowa, Lexis Nexis, Warszawa 2006, s. 17-95; R. Mastalski, Prawo podatkowe I - część ogólna, C.H. Beck, Warszawa 1998, s. 13-14. 
komplementarnych (t.j. Dz.U. 2018, poz. 387). Oba stanowią dochód budżetu państwa, a ich zakres podmiotowy jest bardzo ograniczony. Pierwszy obejmuje przedsiębiorstwa żeglugowe eksploatujące morskie statki handlowe w żegludze międzynarodowej, drugi zaś - obowiązujący od 2017 r. - przedsiębiorstwa okrętowe trudniące się budową lub przebudową statków.

Punktem wyjścia do rozważań jest przedstawienie podatków dochodowych jako źródła dochodów własnych jednostek samorządu terytorialnego. Nie można rozpatrywać uprawnień tych podmiotów do stanowienia podatków dochodowych, kształtowania obciążeń podatkowych oraz poboru tych podatków $\mathrm{w}$ oderwaniu od roli, jaką podatki dochodowe odgrywają w budżetach gmin, powiatów i województw. Dopiero bowiem w tym kontekście można właściwie ocenić zakres przysługujących jednostkom samorządu terytorialnego uprawnień do nakładania ciężarów podatkowych oraz wpływu na ich wymiar i pobór.

Następnie zbadane zostaną uprawnienia państwa i jednostek samorządu terytorialnego do stanowienia podatków, modelowania obciążeń podatkowych oraz wymiaru i poboru podatków dochodowych, również w kontekście historycznym. W ostatniej części opracowania przedstawione będą postulaty dotyczące podziału zadań i kompetencji między państwo i jednostki samorządu terytorialnego w zakresie stanowienia i poboru podatków związane z nowym modelem dochodów własnych tych jednostek.

\section{Podatki dochodowe jako źródło dochodów budżetowych jednostek samorządu terytorialnego}

Podatki dochodowe stanowią zasadnicze źródło dochodów własnych jednostek samorządu terytorialnego. Dochodami własnymi tych jednostek są:

- dla gmin:

a) wpływy z podatku dochodowego od osób fizycznych opłacanego $\mathrm{w}$ formie karty podatkowej (art. 4 ust. 1 pkt 1 lit. e ustawy z 13 listopada 2003 r. o dochodach jednostek samorządu terytorialnego, t.j. Dz.U. 2017, poz. 1453, ze zm.; dalej: u.d.j.s.t.),

b) udział we wpływach $z$ :

- podatku dochodowego od osób fizycznych, wynosi on nominalnie $39,34 \%$ wpływów od podatników tego podatku zamieszkałych na obszarze gminy, z tym że udział ten jest korygowany według zasad określonych $\mathrm{w}$ art. 89 u.d.j.s.t. ${ }^{2}$ (art. 4 ust. 2 u.d.j.s.t.),

2 Zgodnie z art. 89 ust. 1 u.d.j.s.t. udział gmin we wpływach z podatku dochodowego zmniejsza się o liczbę punktów procentowych odpowiadających iloczynowi 3,81 punktu procentowego i wskaźnika obliczonego łącznie dla całego kraju, według zasad określonych w ust. 2 tego artykułu. I tak, np. w latach 2013-2016 wskaźnik udziału gmin we wpływach z podatku dochodowego od osób fizycznych wynosił odpowiednio 37,42\%, 37,53\%, 37,67\% i 37,79\%. Zob. sprawozdanie z wykonania budżetu państwa za poszczególne lata, https:// 
- podatku dochodowego od osób prawnych, wynosi on $6,71 \%$ wpływów od podatników tego podatku posiadających siedzibę na obszarze gminy (art. 4 ust. 3 u.d.j.s.t.),

- dla powiatów - udział we wpływach z:

a) podatku dochodowego od osób fizycznych, wynosi on 10,25\% wpływów od podatników tego podatku zamieszkałych na obszarze powiatu (art. 5 ust. 2 u.d.j.s.t.),

b) podatku dochodowego od osób prawnych, wynosi on 1,40\% wpływów od podatników tego podatku posiadających siedzibę na obszarze powiatu (art. 5 ust. 3 u.d.j.s.t.)

- dla województw - udział we wpływach z:

a) z podatku dochodowego od osób fizycznych, wynosi on 1,60\% wpływów od podatników tego podatku zamieszkałych na obszarze województwa (art. 6 ust. 2 u.d.j.s.t.),

b) podatku dochodowego od osób prawnych, wynosi on 14,75\% wpływów od podatników tego podatku posiadających siedzibę na obszarze województwa (art. 6 ust. 3 u.d.j.s.t.).

Co istotne, zarówno gminy, jak i powiaty i województwa mają udziały we wpływach jedynie części podatku dochodowego od osób fizycznych. Najogólniej rzecz ujmując, podziałowi między budżet państwa i budżety samorządowe podlegają dochody z podatku dochodowego od osób fizycznych opłacanego na zasadach ogólnych (według skali podatkowej z art. 27 ust. 1 u.p.d.f.) oraz z pozarolniczej działalności gospodarczej ustalanego według zasad określonych $\mathrm{w}$ art. 30c u.p.d.f. (według stawki proporcjonalnej 19\%). Podziałowi nie podlegają wpływy z:

- podatku zryczałtowanego pobieranego z tytułów określonych w art. 29 u.p.d.f. (od niektórych przychodów osób podlegających ograniczonemu obowiązkowi podatkowemu), w art. 30 u.p.d.f. (m.in. z tytułu wygranych w konkursach i niektórych umów-zlecenia i o dzieło), w art. 30a i 30b u.p.d.f. (przychody z kapitałów pieniężnych), w art. 30e u.p.d.f. (z odpłatnego zbycia nieruchomości), w art. 30f u.p.d.f. (od dochodów zagranicznej spółki kontrolowanej), w art. 30g u.p.d.f. (od przychodów z tytułu własności środka trwałego położonego na terytorium Polski),

- ryczałtu ewidencjonowanego,

- ryczałtu od przychodów osób duchownych,

- podatku tonażowego,

- podatku od produkcji okrętowej.

www.mf.gov.pl/ministerstwo-finansow/dzialalnosc/finanse-publiczne/budzet-panstwa/ wykonanie-budzetu-panstwa/sprawozdanie-z-wykonania-budzetu-panstwa-roczne. 
Wpływy z tych tytułów stanowią w całości dochód budżetu państwa (art. 2 ust. 3 u.rycz. oraz art. 111 pkt 1 ustawy z 27 sierpnia 2009 r. o finansach publicznych, t.j. Dz.U. 2017, poz. 2077, ze zm.).

Ze sprawozdania z wykonania budżetu państwa za 2016 r. ${ }^{3}$ wynika, że dochody jednostek samorządu terytorialnego (wszystkich) wyniosły 213668930 360,17 zł, z tego dochody własne 106683468 697,30 zł , co stanowiło $49,93 \%$ całości dochodów budżetowych tych jednostek ${ }^{5}$.

Zasadniczą część dochodów własnych jednostek samorządu terytorialnego stanowiły podatki i opłaty. Dochody z tego tytułu wynosiły 75662241 128,48 zł i stanowiły 70,92\% dochodów własnych tych jednostek, przy czym dla: a) gmin było to $75,94 \%$, b) powiatów - $54,29 \%$, c) miast na prawach powiatu $64,65 \%$, d) województw - 85,03\% ${ }^{6}$.

Łącznie wpływy wszystkich jednostek samorządu terytorialnego z podatków dochodowych (karta podatkowa, udziały w podatku dochodowym od osób fizycznych i podatku dochodowym od osób prawnych) wyniosły 48619953 926,33 zł i stanowiły 45,57\% dochodów własnych tych jednostek oraz $66,91 \%$ całości ich dochodów podatkowych, przy czym dla:

- gmin (wszystkich) było to odpowiednio 38,62\% i 50,86\%, w tym:

a) gmin miejskich $-41,67 \%$ i $56,62 \%$,

b) gmin wiejskich - 36,80\% i 47,96\%,

c) gmin miejsko-wiejskich - 38,15\% i 49,57\%,

- miast na prawach powiatu było to odpowiednio $44,45 \%$ i $66,70 \%$,

- powiatów było to odpowiednio $50,11 \%$ i $100 \%$,

- województw było to odpowiednio 85,03\% i $100 \%$.

Wpływy (łącznie wszystkich jednostek samorządu terytorialnego) z podatku dochodowego od osób fizycznych wyniosły za 2016 r. 41108133 705,00 zł, co stanowi 38,53\% dochodów własnych tych jednostek, przy czym dla gmin (wszystkich) było to $36,81 \%$, dla powiatów - 53,21\%, dla miast na prawach powiatu $-40,68 \%$, a dla województw $-18,38 \%$.

${ }^{3}$ Sprawozdanie z wykonania budżetu państwa za okres od 1 stycznia do 31 grudnia 2016 r. Informacja o wykonaniu budżetów jednostek samorządu terytorialnego, Rada Ministrów, 2017, https://www.mf.gov.pl/documents/764034/6023712/20170531_Omowienie+sp rawozdania+za+2016+r.pdf.

${ }^{4}$ Pozostałą część stanowiły dotacje (25,25\% całości dochodów) i subwencja ogólna (24,82\% całości dochodów).

${ }^{5}$ Choć dane odnoszą się jedynie do roku 2016, to rozkład poszczególnych rodzajów dochodów jednostek samorządu terytorialnego w latach wcześniejszych nie różni się zasadniczo od tego z roku 2016. Zob. sprawozdania z wykonania budżetu państwa za lata wcześniejsze, www.mf.gov.pl.

${ }^{6}$ Wyliczenia na podstawie danych ze Sprawozdania z wykonania budżetu państwa za 2016 r., op. cit. Dotyczy to również pozostałych wyliczeń. 
Największy udział we wpływach z podatku dochodowego od osób fizycznych mają miasta na prawach powiatu - 45,39\% (18 658799 423,00 zł), co niewątpliwie wynika $z$ faktu, że przysługuje im udział w podatku dochodowym zarówno w części gminnej, jak i powiatowej. Udział pozostałych gmin (wiejskich, miejskich i miejsko-wiejskich) wyniósł 40,42\% (16 616164489,00 zł), przy czym do gmin wiejskich trafiło $14,54 \%$ wpływów z podatku dochodowego od osób fizycznych w części przypadającej jednostkom samorządu terytorialnego, do gmin miejskich 11,98\%, a do gmin miejsko-wiejskich 13,90\%. Do powiatów trafiło 10,97\% (4 508783 180,00 zł) wpływów z podatku dochodowego od osób fizycznych przypadających jednostkom samorządu terytorialnego, a do województw tylko 3,22\% (1 324386 613,00 zł).

Wpływy (łącznie wszystkich jednostek) z podatku dochodowego od osób prawnych wyniosły za 2016 r. 7441198 539,20 zł, co stanowiło 6,97\% dochodów własnych tych jednostek, przy czym dla gmin (wszystkich) było to $1,72 \%$, powiatów $-1,91 \%$, miast na prawach powiatu $-3,70 \%$, województw $-66,65 \%$.

Największy udział we wpływach z podatku dochodowego od osób prawnych miały województwa - aż 64,53\% (4 802112 058,98zł), zaś najmniejszy powiaty - tylko 2,18\% (161 $794544,72 \mathrm{zł}$ ). Udział miast na prawach powiatu wyniósł 22,83\% (1 198999 092,57zł), zaś gmin (wszystkich) - 10,46\% (778 292 842,93 zł), przy czym: gmin wiejskich - 2,52\% (187 711 312,71 zł), gmin miejskich - 3,70\% (275 201 010,12 zł), gmin miejsko-wiejskich - 4,24\% (315 $380020,10 \mathrm{zł})$.

Wpływy z karty podatkowej w całości stanowią dochód budżetów gminnych, w tym miast na prawach powiatu? W $2016 \mathrm{r}$. wyniosły one $70621682,13 \mathrm{zł}$, z czego 10895 857,25 zł (15,43\%) wpłynęło do gmin wiejskich, 14058560,69 zł (19,90\%) wpłynęło do gmin miejskich, 13408 468,13 zł (18,99\%) wpłynęło do gmin miejsko-wiejskich, a 32258 796,06 zł (45,68\%) wpłynęło do miast na prawach powiatu.

Porównując dochody jednostek samorządu terytorialnego z podatków dochodowych, przede wszystkim z podatku dochodowego od osób fizycznych, z wpływami z pozostałych podatków, łatwo zauważyć, że te pierwsze stanowią prawie $70 \%(66,91 \%)$ całości dochodów podatkowych tych jednostek, przy czym dla powiatów i województw są to w praktyce jedyne wpływy podatkowe, dla miast na prawach powiatu wskaźnik ten wynosi $66,70 \%$, a dla gmin $50,86 \%$ (dla gmin wiejskich $-47,96 \%$, gmin miejskich $-56,62 \%$, a gmin miejsko-wiejskich - 49,57\%). Z pozostałych podatków (od nieruchomości, rolnego, leśnego, od środków transportowych, od czynności cywilnoprawnych oraz od spadków i darowizn), które stanowią dochód jednostek samorządu te-

7 Zgodnie z art. 92 ust. 2 ustawy z 5 czerwca 1998 r. o samorządzie powiatowym, t.j. Dz.U. 2018, poz. 995, miasto na prawach powiatu jest gminą wykonującą zadania powiatu na zasadach określonych $\mathrm{w}$ ustawie o samorządzie powiatowym. 
rytorialnego (gmin i miast na prawach powiatu), jedynie wpływy z podatku od nieruchomości mogą być uznane za porównywalne z wpływami z podatku dochodowego od osób fizycznych, aczkolwiek są one i tak dwukrotnie niższe. Z pierwszego z podatków wyniosły w 2016 r. 20774468 288,33 zł i stanowily $19,47 \%$ dochodów własnych jednostek samorządu terytorialnego, w praktyce gmin i miast na prawach powiatu', a drugiego - 41108 133 705,00 zł i stanowiły $38,53 \%$ dochodów własnych tych jednostek.

Wpływy z pozostałych podatków są nieporównywalnie niższe. Przykładowo, wpływy z podatku rolnego stanowią tylko 3,30\% dochodów własnych gmin $(4,35 \%$ dochodów podatkowych), zaś w miastach na prawach powiatu jedynie $0,04 \%$ dochodów własnych $(0,07 \%$ dochodów podatkowych). Wpływy z podatku od czynności cywilnoprawnych stanowią 2,14\% dochodów własnych gmin $(2,81 \%$ dochodów podatkowych), a w miastach na prawach powiatu 2,63\% dochodów własnych (3,94\% dochodów podatkowych). Wpływy z pozostałych podatków stanowią marginalny udział w dochodach własnych tych jednostek.

Reasumując, wpływy z podatków dochodowych nie tylko stanowią z arytmetycznego punktu widzenia zasadnicze źródło dochodów własnych jednostek samorządu terytorialnego, ale przesądzają o możliwości realizacji przez te podmioty przypisanych im ustawowo zadań własnych, a więc tych, które zaspokajają potrzeby wspólnoty samorządowej'. W związku z tym rodzi się pytanie o wpływ jednostek samorządu terytorialnego na kształt podatków, które stanowią prawie połowę $(45,57 \%)$ dochodów własnych tych podmiotów, przy czym w gminach - 38,62\%, w powiatach - 50,11\%, w miastach na prawach powiatu - 44,45\%, a w budżetach województw - aż $85,03 \%$. Pytanie to wydaje się bardziej zasadne w kontekście regulacji konstytucyjnych nakładających na jednostki samorządu terytorialnego obowiązek zaspokajania potrzeb wspólnoty samorządowej (art. 164 ust. 1 Konstytucji Rzeczypospolitej Polskiej z 2 kwietnia 1997 r., Dz.U. nr 78, poz. 483, ze zm.; dalej: Konstytucja). Zauważyć bowiem należy, że taka regulacja nie tylko wymaga od władzy ustawodawczej zapewnienia tym podmiotom odpowiednich dochodów (art. 167 ust. 1 Konstytucji), co następuje w drodze ustawowej (art. 167 ust. 3 Konstytucji), ale również wpływa na kształt tych, które stanowią ich dochody własne. Te bowiem dochody decydują o możliwości realizacji przez samorząd terytorialny ich zadań własnych. Odnosi się to szczególnie do gminy, jako podstawowej jednostki samorząa terytorialnego (art. 164 ust. 1 Konstytucji), której zadania

8 W przypadku gmin - 27,97\% dochodów własnych i 36,84\% dochodów podatkowych, a w przypadku miast na prawach powiatu - 17,76\% dochodów własnych i $26,65 \%$ dochodów podatkowych.

9 Zob. art. 166 ust. 1 Konstytucji RP i art. 7 ustawy z 8 marca 1990 r. o samorządzie gminnym, t.j. Dz.U. 2018, poz. 994, ze zm., art. 4 ustawy o samorządzie powiatowym i art. 14 ustawy z 5 czerwca 1998 r. o samorząazie województwa, t.j. Dz.U. 2018, poz. 913, ze zm. 
własne są najszersze (art. 164 ust. 3 Konstytucji i art. 7 ust. 1 ustawy o samorządzie gminnym)

\section{Podział zadań i kompetencji w zakresie stanowienia podatków, modelowania obciążeń podatkowych oraz poboru podatków dochodowych między państwo i jednostki samorządu terytorialnego}

Aktem prawnym przesądzającym o uprawnieniach do stanowienia podatków jest Konstytucja RP. W związku z tym należy przywołać przede wszystkim jej art. 84, który wprowadzając zasadę powszechności ponoszenia ciężarów i świadczeń publicznych, w tym podatków, przesądza, że obowiązek ten może wynikać wyłącznie z ustawy. Co istotne, jak wynika z art. 123 ust. 1 Konstytucji, chodzi o ustawę szczególną, określaną przez ustawodawcę konstytucyjnego ustawą podatkową. Jej elementy niezbędne zostały zdefiniowane w art. 217 Konstytucji. Zaliczyć do nich należy przedmiot i podmiot opodatkowania, stawki podatkowe, zasady przyznawania ulg i umorzeń oraz kategorie podmiotów zwolnionych z podatków.

$\mathrm{Z}$ formalnego punktu widzenia władztwo stanowienia (nakładania) danin publicznych przysługuje więc Sejmowi i Senatowi (art. 10 ust. 2 Konstytucji), zaś władzy wykonawczej, w sprawie podatków przede wszystkim Radzie Ministrów, przysługuje inicjatywa ustawodawcza (art. 10 ust. 2 i art. 118 ust. 1 Konstytucji). Ustawa zasadnicza przesądza tym samym, że właściwym miejscem na prowadzenie debaty podatkowej są Sejm i Senat. Ramy formalne tej debaty wynikają z Konstytucji, przede wszystkim z art. 119, który nakazuje rozpatrywanie projektów ustaw przez Sejm w trzech czytaniach (ust. 1 art. 119), a także uprawnia wnioskodawców, posłów i Radę Ministrów, do wnoszenia poprawek (ust. 2 art. 119), oraz regulaminu Sejmu ${ }^{10}$, precyzującego porządek prac Sejmu.

O ile uchwalanie ustaw podatkowych należy niewątpliwie do prerogatyw władzy ustawodawczej, o tyle łatwo dostrzec, że proces legislacyjny toczony w parlamencie jest w zasadzie zwieńczeniem wcześniejszych prac nad projektem takiej ustawy toczonych przede wszystkim w Radzie Ministrów ${ }^{11}$, do

${ }_{10}$ Uchwała Sejmu Rzeczypospolitej Polskiej z 30 lipca 1992 r. - Regulamin Sejmu Rzeczypospolitej Polskiej, t.j. M.P. 2012, nr 32, ze zm.

${ }^{11}$ Co prawda, projekty rządowe nie stanowią w pracach Sejmu najliczniejszej grupy projektów ustaw podatkowych, są to jednak projekty o największym ciężarze gatunkowym, dotykające całego systemu podatkowego, a nie tylko - jak ma to miejsce w przypadku projektów poselskich lub obywatelskich - niektórych z jego elementów. W latach 1991-2015 (I-VII kadencja Sejmu) do laski marszałkowskiej wpłynęło łącznie 471 projektów ustaw podatkowych, a więc takich, których główną materię stanowiły ustawy nakładające nowy obowiązek podatkowy lub zmiany ustaw podatkowych. Z tego projektów rządowych było 186, poselskich 195, komisyjnych 65, senackich 18, prezydenckich 3, zaś obywatelskich 4 . 
której należą, zgodnie z art. 146 ust. 2 Konstytucji, sprawy polityki państwa nie zastrzeżone dla innych organów państwa i samorządu terytorialnego. Niewątpliwie w gestii Rady Ministrów pozostaje kształtowanie polityki podatkowej państwa, co należy w obecnym stanie prawnym do ministra właściwego do spraw finansów publicznych ${ }^{12}$. Ta prerogatywa obejmuje wszystkie rodzaje podatków i opłat, zarówno w całości wpływające do budżetu państwa, jak i podatki samorządowe (stanowiące dochód jednostek samorządu terytorialnego) oraz dzielone między budżet państwa i budżety samorządowe. Tym samym w gestii Rady Ministrów leży kształtowanie polityki opodatkowania dochodów (przychodów) zarówno osób fizycznych, prawnych, jak i jednostek organizacyjnych nieposiadających osobowości prawnej.

Co prawda, ustawodawstwo zwykłe umożliwia nałożenie na mieszkańców gminy ciężaru podatkowego innego niż wynikający z ustawy podatkowej, jednak: po pierwsze - może to nastąpić wyłącznie przez samoopodatkowanie się mieszkańców na cele publiczne mieszczące się w zakresie zadań i kompetencji organów gminy, co dokonuje się w drodze referendum lokalnego ${ }^{13}$, po drugie - ten rodzaj daniny nie jest uznawany przez doktrynę i orzecznictwo za podatek w rozumieniu Konstytucji RP, bowiem nie ma wszystkich jego cech ${ }^{14}$. Samoopodatkowanie jest więc szczególną formą „przekazania” przez mieszkańców gminy części ich dochodu (majątku) na rzecz społeczności lokalnej, które następuje w wyniku decyzji podejmowanej przez mieszkańców i, co za tym idzie, nie może być świadczeniem narzuconym w drodze przymusu władzy ustawodawczej ${ }^{15}$.

Zob. P. Bartosiewicz, J. Kulicki, Projekty ustaw podatkowych w ocenie Biura Analiz Sejmowych Kancelarii Sejmu [w:] Wybrane zagadnienia stanowienia i stosowania polskiego prawa podatkowego, red. J. Kulicki, Wydawnictwo Sejmowe, Warszawa 2017, s. 20.

12 Zob. art. 149 ust. 1 Konstytucji oraz: art. 8 ust. 1 i ust. 2 pkt 1 ustawy z 4 września 1997 r. o działach administracji rządowej, t.j. Dz.U. 2018, poz. 762, ze zm.; art. 7 ust. 1 i 2 ustawy z 8 sierpnia 1996 r. o Radzie Ministrów, t.j. Dz.U. 2012, poz. 392, ze zm., oraz rozporządzenie Prezesa Rady Ministrów z 10 stycznia 2018 r. w sprawie szczególnego zakresu działania Ministra Finansów, Dz.U. poz. 92.

${ }_{13}$ Zob. art. 2 ust. 2 ustawy z 15 września 2000 r. o referendum lokalnym, t.j. Dz.U. 2016, poz. 400 , ze zm.

14 Zob. M. Hyski, Problemy samoopodatkowania się mieszkańców gminy, „Infrastruktura i Ekologia Terenów Wiejskich" 2009, nr 4, s. 139-141; http://yadda.icm.edu.pl/agro/ element/bwmeta1.element.dl-catalog-1b19e7e1-e1a9-4cd3-98ee-2871ad19139e/c/Hyski. pdf, i cyt. tam literaturę. Inaczej: E. Kornberger-Sokołowska, Rola jednostek samorzadu terytorialnego $w$ kształtowaniu i poborze podatków stanowiących ich dochody [w:] Dylematy reformy systemu podatkowego w Polsce, red. H. Dzwonkowski, J. Kulicki, Wydawnictwo Sejmowe, Warszawa 2016, s. 192-193.

15 Zob. też B. Brzeziński, Prawo podatkowe. Zarys wykładu, Dom Organizatora, Toruń 1995, s. 12, oraz C. Kosikowki, E. Ruśkowski, Finanse publiczne i prawo finansowe, KiK, Warszawa 1995, s. 140. 
Jakikolwiek wpływ jednostek samorządu terytorialnego na kształt ustaw podatkowych $\mathrm{w}$ zakresie podatków dochodowych możliwy jest jedynie na zasadach określonych w ustawie z 6 maja 2005 r. o Komisji Wspólnej Rządu i Samorządu Terytorialnego oraz przedstawicielach Rzeczypospolitej Polskiej w Komitecie Regionów Unii Europejskiej (Dz.U. nr 90, poz. 759). Zgodnie $\mathrm{z}$ art. 3 przywołanej ustawy do zadań tej Komisji należy między innymi: a) dokonywanie przeglądów i ocen warunków prawnych i finansowych funkcjonowania samorządu terytorialnego (pkt 2), b) analizowanie informacji o przygotowywanych projektach aktów prawnych, dokumentów i programów rządowych dotyczących problematyki samorządu terytorialnego, w szczególności przewidywanych skutków finansowych (pkt 3). W żaden sposób przepisy tej ustawy nie przyznają jednak jednostkom samorządu terytorialnego prawa współdecydowania o kształcie polityki podatkowej państwa oraz przyjmowanych poszczególnych rozwiązaniach ustawowych (legislacyjnych).

Choć dochody z podatków dochodowych, czy to z karty podatkowej (w przypadku gmin), czy też w formie udziału we wpływach z podatków: dochodowego od osób fizycznych opłacanego na zasadach ogólnych oraz dochodowego od osób prawnych, stanowią zasadniczą część dochodów własnych jednostek samorządu terytorialnego, to $\mathrm{w}$ zasadzie poza przypadkiem określonym $\mathrm{w}$ art. 18 ust. 2 u.d.j.s.t. jednostki te nie mają żadnego wpływu na pobór tych podatków. Uprawnienia w tym zakresie przysługują organom skarbowym (podatkowym) administracji rządowej, które są właściwe do wymiaru, kontroli i poboru tych podatków (np. art. 45 ust. 6 u.p.d.f., art. 30 ust. 1 u.rycz., art. 27 ustawy o podatku dochodowym od osób prawnych.). Rozwiązanie takie budzi szczególne zastrzeżenia w przypadku podatku dochodowego od osób fizycznych opłacanego w formie karty podatkowej. Podatek ten bowiem w całości stanowi dochód budżetów gminnych (art. 4 ust. 1 pkt 1 lit. e u.d.j.s.t.). Tymczasem zarówno rozstrzygnięcie wniosku o zastosowanie tej formy opodatkowania, jak i ustalenie wysokości podatku, w tym przyznanie ulg, które ustawodawca uzależnia od uznania organu podatkowego, należą do naczelnika urzędu skarbowego (np. art. 27 ust. 2 i 3 , art. 30 ust. 1 i 2 u.rycz.). Co istotne, organ ten nie jest zobowiązany do zasięgania w tej sprawie opinii właściwego organu jednostki samorządu terytorialnego, na której terenie prowadzona jest działalność gospodarcza.

Taki stan rzeczy jest $\mathrm{w}$ istocie konsekwencją przejęcia przez obecne ustawodawstwo rozwiązań obowiązujących w poprzednim systemie, sprzed $1990 \mathrm{r}$. Dotyczy to zarówno rozwiązań dotyczących podatków dochodowych ${ }^{16}$, jak i podziału zadań i kompetencji między samorząd i państwo oraz dochodów podatkowych między budżet państwa i budżety samorządowe.

16 Szerzej zob. J. Kulicki, Reforma źródeł przychodów jako warunek konieczny przebudowy obecnego modelu opodatkowania dochodów, „Zeszyty Prawnicze BAS” 2017, nr 3(55), s. 9-32. 
Oczywiście, porównując wcześniejsze i obecne rozwiązania, nie można abstrahować od różnic w pozycji ustrojowej obecnych jednostek samorządu terytorialnego i wcześniejszych terenowych organów władzy i administracji państwowej ${ }^{17}$. Niestety takie porównanie wypada na niekorzyść obecnych rozwiązań. Konstytucja z 1952 r. de facto eliminowała samorząd terytorialny jako formę organizacji społeczności lokalnej. Ustawą z 8 marca 1990 r. przywrócono w Polsce samorząd terytorialny, rozbudowując następnie przepisy konstytucyjne dotyczące tego samorządu w ustawie zasadniczej z 1997 r., do decyzji ustawodawcy zwykłego pozostawiając kwestię określenia samodzielności finansowej tych podmiotów (art. 167 Konstytucji).

Analiza obecnego stanu prawnego i faktycznego obowiązującego w tym zakresie wskazuje, że samodzielność ta jest mocno ograniczona, o czym świadczy nie tylko skala subwencji i dotacji celowych stanowiących dochody jednostek samorządu terytorialnego (ok. 50\%), ale przede wszystkim udział podatków dochodowych w dochodach własnych (ok. 45\%) oraz jedynie nieco ponad $20 \%$ udziału podatków pobieranych przez jednostki samorządu terytorialnego w dochodach własnych. Oznacza to, że gros dochodów własnych pochodzących z podatków pobieranych jest przez organy administracji rządowej, naczelników urzędów skarbowych (prawie 80\%). Oczywiście, wskaźniki te są różne w poszczególnych rodzajach jednostek samorządu terytorialnego: w gminach podatki pobierane przez organy gminne stanowiły w 2016 r. 33,83\% dochodów własnych gmin i 44,54\% ich dochodów podatkowych, w miastach na prawach powiatu $18,61 \%$ dochodów własnych i $27,92 \%$ dochodów podatkowych tych jednostek, natomiast powiaty i województwa nie pobierają żadnych dochodów podatkowych.

W związku z tym warto zauważyć, że obecny system dochodów podatkowych zaliczanych do dochodów własnych jednostek samorządu terytorialnego został w istotny sposób ograniczony w stosunku do rozwiązań obowiązujących przed 1990 r. Na przykład ustawa z 20 lipca 1983 r. o systemie rad narodowych i samorządu terytorialnego, Dz.U. 1988, nr 26, poz. 183, ze zm., do dochodów własnych budżetów terenowych, które stanowiły podstawę samodzielności finansowej rady narodowej (art. 41 ust. 2 tej ustawy), zaliczała w art. 44 ust. 1: a) podatki od przedsiębiorstw państwowych, dla których organem założycielskim był terenowy organ administracji państwowej, b) podatki od spółdzielni, z wyjątkiem spółdzielni rozliczających się z budżetem centralnym, c) podatek od płac, w wysokości 85\% wpływów z tego podatku, d) podatek od nieruchomości od jednostek organizacyjnych gospodarki uspołecznionej, e) podat-

17 Zob. rozdział 6, art. 43-55, Konstytucji PRL z 22 lipca 1952 r. w brzmieniu obowiązującym przed 19 marca 1990 r., oraz art. 43-47 Konstytucji z 1952 r. w brzmieniu nadanym ustawą z 8 marca 1990 r. o zmianie Konstytucji Rzeczypospolitej Polskiej i rozdział 5, art. 70-75, ustawy konstytucyjnej z 17 października 1992 r., a także rozdział VII, art. 163172, obecnej Konstytucji. 
ki obrotowy i dochodowy od osób fizycznych i osób prawnych niebędących jednostkami gospodarki uspołecznionej, f) podatek wyrównawczy, g) podatek rolny i inne podatki i opłaty od nieruchomości rolnych, h) podatki i opłaty pobierane na podstawie przepisów o podatkach i opłatach terenowych, i) podatek od spadków i darowizn, j) opłatę skarbową, k) inne podatki i opłaty, uznane przez przepisy szczególne za dochody budżetów terenowych ${ }^{18}$.

Przywracając do życia samorząd terytorialny, do dochodów gmin zaliczono: a) podatek rolny, b) podatek od nieruchomości, c) podatek od środków transportowych (od 1992 r.), d) podatek od spadków i darowizn, e) kartę podatkową, f) podatek od posiadania psów, g) podatek leśny (od 1992 r.), h) opłatę skarbową, i) opłaty lokalne, j) udziały w podatku dochodowym od osób fizycznych $(15 \%)^{19} \mathrm{i}$ podatku dochodowym od osób prawnych $(5 \%)^{20}$. Te źródła podatkowe dochodów gmin zostały powtórzone w następnych ustawach: z 10 grudnia 1993 r. o finansowaniu gmin, Dz.U. 1998, nr 30, poz. 164, ze zm., art. 4; z 26 listopada 1998 r. o dochodach jednostek samorządu terytorialnego w latach 1999-2003, Dz.U. nr 150, poz. 983, ze zm., art. 3 oraz w obecnej ustawie o dochodach jednostek samorządu terytorialnego.

Analiza tych przepisów wskazuje jednoznacznie, że podjęte działania w zakresie odbudowy samorządu terytorialnego nie zostały w żaden sposób skorelowane z próbą reformy dochodów tego samorządu. $\mathrm{W}$ istocie zmiany, które nastąpily w tym obszarze, związane były ze zmianami w systemie opodatkowania dochodów osób fizycznych i prawnych (scalenie w jednym podatku dochodowym podatku od płac, podatku od wynagrodzeń, podatku wyrównawczego, podatku dochodowego, podatku rolnego od działów specjalnych produkcji rolnej oraz wprowadzenie podziału na osoby fizyczne i osoby prawne w miejsce podziału na jednostki gospodarki uspołecznionej oraz ludność i jednostki gospodarki nieuspołecznionej), co spowodowało, że dotychczasowe dochody własne $\mathrm{z}$ tych tytułów zastąpiono udziałami w dochodach z podatku dochodowego od osób fizycznych i podatku dochodowego od osób prawnych.

W okresie 1990-2017 zmieniała się jedynie wielkość udziałów poszczególnych jednostek samorządu terytorialnego $\mathrm{w}$ dochodach $\mathrm{z}$ tych podatków, co

18 Zob. również uregulowania wcześniejsze: ustawę z 20 marca 1946 r. o finansach komunalnych, Dz.U. nr 19, poz. 129, ze zm.; ustawę z 1 lipca 1958 r. o dochodach rad narodowych, Dz.U. nr 44, poz. 214, ze zm.; a także art. 17-19 ustawy z 25 listopada 1970 r. - Prawo budżetowe, Dz.U. nr 29, poz. 244, ze zm., i art. 19 i 20 ustawy z 3 grudnia 1984 r. - Prawo budżetowe, Dz.U. nr 56, poz. 283, ze zm.

19 Pierwotnie udział $50 \%$.

20 Zob. art. 1 i 3 ustawy z 14 grudnia 1990 r. o dochodach gmin i zasadach ich subwencjonowania w latach 1991-1993 oraz o zmianie ustawy o samorządzie terytorialnym, Dz.U. nr 89, poz. 518, ze zm. Początkowo również podatków: od płac, od wynagrodzeń i wyrównawczego (udział 30\%). 
w niczym nie poprawiało samodzielności finansowej tych podmiotów. W ponad 70\% (w 2016 r. - 74,35\%) wydatki jednostek samorządu terytorialnego finansowane są z dochodów przekazywanych im przez organy administracji rządowej. Bez znaczenia pozostaje fakt, że dochody te wynikają z ustaw. Ustawa zawsze może być zmieniona, a dochody ograniczone, np. przez zmiany w podatkach, na które jednostki samorządu terytorialnego nie mają wpływu, podobnie jak nie mają wpływu na skuteczność administracji rządowej w poborze podatków, które w całości stanowią ich dochody bądź w których mają zagwarantowany udział.

Reasumując, w obecnym stanie prawnym jednostkom samorządu terytorialnego nie przysługują żadne uprawnienia w zakresie nakładania ciężarów podatkowych (stanowieniu podatków). Zakres władztwa podatkowego jednostek samorządowych ograniczony został przez Konstytucję RP do modelowania (kształtowania) w granicach upoważnienia ustawowego niektórych elementów konstrukcyjnych podatku wpływających na wysokość obciążeń podatkowych poszczególnych podatników. Co istotne, uprawnienie to odnosi się wyłącznie do podatków lokalnych (art. 168 Konstytucji), a więc podatku od nieruchomości, podatku od środków transportowych, opłat: od posiadania psów, targowej, miejscowej, uzdrowiskowej i reklamowej, w których obowiązek podatkowy wynika z ustawy z 12 stycznia $1991 \mathrm{r}$. o podatkach i opłatach lokalnych, t.j. Dz.U. 2017, poz. 1785, ze zm., oraz podatku rolnego i podatku leśnego, w których obowiązek podatkowy wynika, odpowiednio z ustawy z 15 listopada 1984 r. o podatku rolnym, t.j. Dz.U. 2017, poz. 1892, i ustawy z 30 października 202 r. o podatku leśnym, t.j. Dz.U. 2017, poz. 1821. Uprawnienia do ustalania wysokości podatków i opłat ograniczają się więc w obecnym stanie prawnym do danin pobieranych przez samorządowe (gminne) organy podatkowe (wójtów, burmistrzów, prezydentów miast). Nie obejmują natomiast pozostałych podatków zaliczanych przez ustawę o dochodach jednostek samorządu terytorialnego do dochodów własnych tych jednostek, nawet stanowiących w całości dochody ich budżetów. Dotyczy to więc również podatku dochodowego opłacanego w formie karty podatkowej, podatku od czynności cywilnoprawnych i podatku od spadków i darowizn (art. 4 ust. 1 pkt 1 lit. e, g, h u.d.j.s.t.). Uprawnienia jednostek samorządu terytorialnego zostały w tym wypadku ograniczone do wyrażenia zgody lub jej odmowy na umorzenie, odroczenie terminu płatności, rozłożenie płatności na raty oraz zwolnienie płatnika z pobrania podatku lub ograniczenia jego poboru (art. 18 ust. 2 i 3 u.d.j.s.t.). W odniesieniu do podziału kompetencji między państwo i jednostki samorządu terytorialnego w zakresie stanowienia i poboru podatków mamy więc $\mathrm{w}$ istocie do czynienia $\mathrm{z}$ modelem scentralizowanym. Uprawnienia samorządu są mocno reglamentowane, zaś prerogatywy państwa nad wyraz eksponowane, co prowadzi do uzależnienia finansów jednostek samorządu terytorialnego od bieżącej polityki państwa. 


\section{Postulaty dotyczące podziału kompetencji w zakresie władztwa podatkowego między państwo i samorząd terytorialny}

Jak wynika z dotychczasowych ustaleń, obowiązujące rozwiązania w analizowanym obszarze w istotny sposób ograniczają możliwości jednostek samorządu terytorialnego do kształtowania źródeł ich zasobów własnych, skazując je na swego rodzaju dyktat Sejmu i Senatu, którym Konstytucja RP przyznała uprawnienia do stanowienia podatków, a de facto - mając na względzie obowiązującą w Polsce praktykę „pisania” ustaw i procedowania nad nimi w parlamencie $^{21}$ - dyktat władzy wykonawczej.

Moim zdaniem stan taki jest nie do utrzymania w dłuższej perspektywie czasowej, oczywiście, o ile poważnie traktujemy zapisy ustawy zasadniczej dotyczące samorządu terytorialnego, jego zadań i kompetencji. Konieczna jest więc istotna zmiana:

- w kształcie dochodów własnych jednostek samorządu terytorialnego z podatków dochodowych,

- w uprawnieniach jednostek samorządu terytorialnego w zakresie ich wpływu na kształt podatków dochodowych, które stanowią ich dochody własne,

- w uprawnieniach jednostek samorządu terytorialnego do wymiaru i poboru podatków dochodowych stanowiących ich dochody własne.

Chodzi więc o wypracowanie nowego modelu podziału kompetencji między państwo i jednostki samorządu terytorialnego w zakresie opodatkowania dochodów osób fizycznych i prawnych. Modelu, który w większym stopniu akcentowałby samodzielność samorządu terytorialnego, przenosząc na niego z jednej strony znaczną część uprawnień do kształtowania polityki podatkowej, z drugiej odpowiedzialność za pobór podatków dochodowych stanowiących jego dochody własne.

Zmiany te powinny być elementem kompleksowej reformy samorządu terytorialnego (jego kształtu), dochodów jednostek samorządu terytorialnego (zarówno w zakresie dochodów własnych, jak i subwencji i dotacji), a także reformy opodatkowania dochodów osób fizycznych i prawnych, której podstawą

${ }^{21}$ Szerzej zob. P. Bartosiewicz, J. Kulicki, Projekty ustaw podatkowych $w$ ocenie Biura Analiz Sejmowych, op. cit., s. 13-44; A. Karwowska-Sokołowska, A. Niemczewski, Ustawy podatkowe w ocenie Biura Analiz i Dokumentacji oraz Biura Legislacyjnego Kancelarii Senatu [w:] Wybrane zagadnienia stanowienia i stosowania polskiego prawa podatkowego, red. J. Kulicki, Wydawnictwo Sejmowe, Warszawa 2017, s. 119-150, oraz J. Kulicki, Obecny i pożądany zakres i treść konstytucyjnej regulacji zasady władztwa podatkowego państwa w Konstytucji RP z 1997 r. [w:] Dylematy reformy systemu podatkowego w Polsce, red. H. Dzwonkowski, J. Kulicki, Wydawnictwo Sejmowe, Warszawa 2016, s. 41-49. 
powinno być ukształtowanie na nowo źródeł przychodów, oraz administracji skarbowej (podatkowej) odpowiedzialnej za pobór podatków.

Większość z tych zagadnień wykracza poza ramy niniejszego artykułu. Bezpośredni wpływ na poruszane $\mathrm{w}$ nim kwestie ma bez wątpienia system opodatkowania dochodów osób fizycznych i prawnych. Obecny kształt tego systemu niewiele różni się od modelu obowiązującego przed 1992 r. Podział sektorowy na jednostki gospodarki uspołecznionej i nieuspołecznionej oraz ludność, obowiązujący przed 1989 r., zastąpiono podziałem według kryterium formy prawnej podatnika (osoby fizyczne, osoby prawne, jednostki organizacyjne niemające osobowości prawnej), nie dokonując żadnych zmian w źródłach przychodów, co przy zmienionych warunkach społeczno-gospodarczych doprowadziło do niezliczonej ilości zmian i daleko posuniętej kazuistyki poszczególnych unormowań.

Filarem reformy opodatkowania dochodów osób fizycznych i prawnych w Polsce powinna być, moim zdaniem, zmiana w wyodrębnianiu i definiowaniu źródeł przychodów. W tym zakresie proponuję wyodrębnićc ${ }^{22}$ :

- przychody z aktywności zawodowej i obywatelskiej (społecznej), obejmujące przychody z:

a) pracy najemnej, bez względu na stosunek prawny łączący pracownika z pracodawcą,

b) czynności społecznych lub obywatelskich,

c) pracy na własny rachunek, o ile nie byłaby ona zaliczana do aktywności inwestycyjnej,

d) prowadzenia gospodarstwa rolnego, o ile przychody z tego tytułu nie byłyby zaliczone do przychodów z aktywności inwestycyjnej,

- przychody z aktywności inwestycyjnej, definiowanej jako każde rozporządzenie majątkiem, o ile przychody z tego tytułu nie są zaliczane do przychodów $\mathrm{z}$ dysponowania majątkiem osobistym w celach nieinwestycyjnych lub przychodów z aktywności zawodowej i obywatelskiej,

- przychody $z$ dysponowania majątkiem osobistym w celach nieinwestycyjnych,

- przychody ze środków pomocowych, w tym zbiórek publicznych,

- przychody ze świadczeń związanych z zabezpieczeniem społecznym, między innymi świadczeń emerytalnych, rentowych, chorobowych i każdego innego świadczenia wynikającego z zabezpieczenia społecznego podatnika,

- przychody $z$ dysponowania majątkiem przez jednostki działające $\mathrm{w}$ interesie publicznym, w tym jednostki samorządu terytorialnego, samorządowe zakłady budżetowe, organizacje pożytku publicznego.

\footnotetext{
${ }^{22}$ Szerzej zob. J. Kulicki, Reforma źródeł przychodów jako warunek, op. cit., s. 9-31.
} 
Wraz z nowym kształtem źródeł przychodów należałoby wprowadzić zasadę odrębnego traktowania dla celów podatkowych dochodów $\mathrm{z}$ aktywności inwestycyjnej oraz dochodów z pozostałych źródeł. Umożliwiłoby to przypisanie wprost wpływów z podatku dochodowego jednostkom samorządu terytorialnego oraz państwu. W tym zakresie proponuję następujący podział:

- podatek dochodowy od dochodów z aktywności inwestycyjnej stanowiłby w całości dochód budżetu państwa,

- podatek dochodowy od dochodów z pozostałych źródeł przychodów stanowiłby dochód jednostek samorządu terytorialnego.

Do rozstrzygnięcia pozostawałyby następujące kwestie:

- podział wpływów z podatku między poszczególne rodzaje jednostek samorząa terytorialnego,

- właściwość organów podatkowych (rządowych lub samorządowych) do poboru podatku stanowiącego dochód własny jednostek samorządu terytorialnego, przy czym $\mathrm{w}$ razie przyznania uprawnień $\mathrm{w}$ tym zakresie samorządom rozstrzygnięcia wymagać będzie, które $\mathrm{z}$ tych jednostek powinny otrzymać takie uprawnienia: gminy, powiaty czy województwa,

- czy i w jakim zakresie budżet państwa powinien partycypować we wpływach z podatku dochodowego stanowiącego dochód jednostek samorządu terytorialnego.

Oczywiście, przyjęcie proponowanego modelu opodatkowania dochodów i związanego $\mathrm{z}$ tym podziału wpływów między budżet państwa i budżety samorządowe nie musi wiązać się z przyznaniem jednostkom samorządu terytorialnego uprawnień do wymiaru i poboru podatku stanowiącego ich dochody własne. Pozostawienie tych uprawnień organom podatkowym administracji rządowej byłoby najprostszym i wydaje się najoczywistszym rozwiązaniem. Do rozstrzygnięcia pozostawałaby w takim wypadku jedynie kwestia podziału wpływów z tego podatku między gminy, powiaty i województwa, co oczywiście musiałoby zostać powiązane z podziałem zadań i kompetencji między te jednostki. Model ten różniłby się od obecnego jednoznacznym przypisaniem jednostkom samorządu terytorialnego wpływów z podatku dochodowego jako źródła ich dochodów własnych (obecnie mają jedynie udział w dochodach $\mathrm{z}$ tego podatku, co zbliża je do subwencji ${ }^{23}$ ). Umożliwiłoby to jednocześnie przyznanie samorządom wpływu na ustalanie ulg w zapłacie podatku, a także - co wymagałoby już jednak zmiany przepisów - na politykę państwa w zakresie opodatkowania dochodów osób fizycznych osiągających przychody z innych źródeł niż aktywność inwestycyjna. Nie rozwiązałoby natomiast

${ }^{23}$ Zob. E. Kornberger-Sokołowska, Rola jednostek samorzadu terytorialnego, op. cit., s. 192. 
problemu braku wpływu jednostek samorządu terytorialnego na prowadzenie własnej polityki podatkowej co do opodatkowania dochodów, nawet w obecnej formule wynikającej z art. 168 Konstytucji. Wpływ taki mógłby zostać zapewniony jedynie w sytuacji powierzenia jednostkom samorządu terytorialnego uprawnień w zakresie wymiaru i poboru podatku. Mogłoby to być jednak trudne w obecnym kształcie samorządu terytorialnego w Polsce, co oczywiście nie oznacza, że niemożliwe. Wymagałoby to jednak rozstrzygnięcia, czy potrzebne są w Polsce trzy stopnie samorządu terytorialnego, który z nich należałoby wyeliminować ( $w$ razie eliminacji gminy konieczna byłaby zmiana Konstytucji - zob. jej art. 164 ust. 1), który uczynić wiodącym i tym samym przyznać mu uprawnienia do wymiaru i poboru podatku dochodowego oraz ewentualnie wpływ na kształtowanie obowiązku podatkowego w tym podatku. Wprowadzenie takiej zmiany wiązałoby się jednocześnie ze zmianami w ustroju administracji skarbowej (podatkowej) i podziale kompetencji między organy administracji rządowej i samorządowej. W praktyce doszłoby więc do ukształtowania nowego modelu finansów publicznych, w którym jednostki samorządu terytorialnego przestałyby pełnić w istocie - biorąc oczywiście pod uwagę zmiany ustrojowe, jakie zaszły w ostatnim ćwierćwieczu - rolę zbliżoną do roli terenowych organów władzy i administracji państwowej z okresu PRL-u. Taka reforma wymagałaby jednak zmian o charakterze konstytucyjnym, co w obecnych realiach jest mało prawdopodobne, jednak, moim zdaniem, konieczne dla budowy silnego państwa opartego na idei samorządności. Możliwe jest natomiast wprowadzenie zasygnalizowanych wcześniej zmian w modelu opodatkowania dochodów i połączenie ich ze zmianami w zdefiniowaniu dochodów własnych jednostek samorządu terytorialnego. Możliwe jest również przyznanie tym jednostkom wpływu na kształtowanie polityki podatkowej państwa w zakresie podatków stanowiących ich dochody własne. W tym wypadku wystarczy wprowadzenie jednoznacznego zapisu w ustawie o Komisji Wspólnej Rządu i Samorządu Terytorialnego.

\section{Podsumowanie}

Dokonana analiza obecnych regulacji prawnych dotyczących realizacji władztwa podatkowego państwa $w$ dziedzinie opodatkowania dochodów osób fizycznych i prawnych w Polsce wskazuje jednoznacznie, że zarówno w sprawie stanowienia podatków, jak i ich wymiaru i poboru jednostki samorządu terytorialnego nie mają żadnych kompetencji. Stanowienie podatków należy, zgodnie z unormowaniami konstytucyjnymi, do Sejmu i Senatu. Za kształt polityki podatkowej odpowiada zaś w praktyce władza wykonawcza. Wymiar i pobór podatków dochodowych, zarówno od osób prawnych, jak i fizycznych, również $\mathrm{w}$ formie karty podatkowej, w całości stanowiący dochód gmin, zostały przekazane w gestię organów skarbowych administracji rządowej. Od decyzji 
gmin zależy jedynie przyznanie podatnikom i płatnikom ulg w zapłacie podatku dochodowego $\mathrm{w}$ formie karty podatkowej. Żadnych kompetencji podatkowych nie mają natomiast powiaty i województwa.

Podatki dochodowe to zasadnicze źródło dochodów własnych jednostek samorządu terytorialnego. Stanowią prawie połowę tych dochodów, a w województwach ponad $80 \%$. Jeżeli pod uwagę weźmiemy jedynie wpływy podatkowe, to okazuje się, że podatki dochodowe stanowią prawie 70\% dochodów podatkowych jednostek samorządu terytorialnego.

Obowiązujące regulacje w istotny sposób ograniczają samodzielność finansową jednostek samorządu terytorialnego, co jest konsekwencją przyjęcia przez obecne ustawodawstwo rozwiązań obowiązujących przed 1990 r., i próby dostosowania ich do nowej sytuacji ustrojowej, zamiast podjęcia prac nad reformą finansów publicznych, uwzględniającą powrót do idei samorządu terytorialnego z okresu międzywojennego. Wydaje się, że nieunikniona jest kompleksowa reforma samorządu terytorialnego, której elementami powinny stać się zmiany:

- w kształcie dochodów własnych jednostek samorząa terytorialnego z podatków dochodowych,

- w uprawnieniach jednostek samorządu terytorialnego w zakresie ich wpływu na kształt podatków dochodowych, które stanowią ich dochody własne,

- w uprawnieniach jednostek samorządu terytorialnego do wymiaru i poboru podatków dochodowych stanowiących ich dochody własne.

Mogłyby być one wprowadzane w dwóch etapach.

Etap pierwszy wiązałby się $\mathrm{z}$ przebudową modelu opodatkowania dochodów osób fizycznych i prawnych, co pozwoliłoby wprost na przypisanie wpływów z podatku dochodowego jednostkom samorządu terytorialnego i budżetowi państwa. Możliwe byłoby również zwiększenie wpływu jednostek samorządu terytorialnego na kształtowanie polityki podatkowej państwa w dziedzinie opodatkowania dochodów osób fizycznych podatkiem dochodowym w całości zasilającym ich budżety.

Etap drugi wiązałby się z koniecznością przebudowy modelu samorządu terytorialnego, co umożliwiłoby przyznanie tym podmiotom uprawnień do wymiaru i poboru podatku dochodowego oraz kształtowania lokalnej polityki podatkowej.

\section{Bibliografia}

Bartosiewicz P., Kulicki J., Projekty ustaw podatkowych w ocenie Biura Analiz Sejmowych Kancelarii Sejmu [w:] Wybrane zagadnienia stanowienia i stosowania polskiego prawa podatkowego, red. J. Kulicki, Wydawnictwo Sejmowe, Warszawa 2017. 
Bień-Kacała A., Zasada władztwa daninowego w Konstytucji RP z 1997 r., Dom Organizatora, Toruń 2005.

Brzeziński B., Prawo podatkowe. Zarys wykładu, Dom Organizatora, Toruń 1995.

Dębowska-Romanowska T., Istota i treść władztwa finansowego - samowola finansowa (samowola podatkowa) - zagadnienia pojęciowe [w:] Konstytucja, ustrój i system finansowy państwa. Księga pamiątkowa ku czci prof. Natalii Gajl, Warszawa 1999.

Hyski M., Problemy samoopodatkowania się mieszkańców gminy, „Infrastruktura i Ekologia Terenów Wiejskich” 2009, nr 4.

Karwowska-Sokołowska A., Niemczewski A., Ustawy podatkowe w ocenie Biura Analiz i Dokumentacji oraz Biura Legislacyjnego Kancelarii Senatu [w:] Wybrane zagadnienia stanowienia i stosowania polskiego prawa podatkowego, red. J. Kulicki, Wydawnictwo Sejmowe, Warszawa 2017.

Kornberger-Sokołowska E., Rola jednostek samorządu terytorialnego w kształtowaniu i poborze podatków stanowiących ich dochody [w:] Dylematy reformy systemu podatkowego w Polsce, red. H. Dzwonkowski, J. Kulicki, Wydawnictwo Sejmowe, Warszawa 2016.

Kosikowski C., Ustawa podatkowa, Lexis Nexis, Warszawa 2006.

Kosikowki C., Ruśkowski E., Finanse publiczne i prawo finansowe, KiK, Warszawa 1995.

Kulicki J., Obecny i pożądany zakres i treść konstytucyjnej regulacji zasady władztwa podatkowego państwa $w$ Konstytucji RP z 1997 r. [w:] Dylematy reformy systemu podatkowego w Polsce, red. H. Dzwonkowski, J. Kulicki, Wydawnictwo Sejmowe, Warszawa 2016.

Kulicki J., Reforma źródeł przychodów jako warunek konieczny przebudowy obecnego modelu opodatkowania dochodów, „Zeszyty Prawnicze BAS” 2017, nr 3(55).

Kulicki J., Zakres władztwa podatkowego w obecnym systemie prawnym $w$ Polsce, seria „Analizy BAS” nr 16 (41), 2010, http://www.bas.sejm.gov.pl/analizy.php.

Mastalski R., Prawo podatkowe I - część ogólna, C.H. Beck, Warszawa 1998.

\section{Akty prawne}

Konstytucja Polskiej Rzeczypospolitej Ludowej z 22 lipca 1952 r., t.j. Dz.U. 1976, nr 7, poz. 36, ze zm.

Konstytucja Rzeczypospolitej Polskiej z 2 kwietnia 1997 r., Dz.U. nr 78, poz. 483, ze zm.

Ustawa z 20 marca 1946 r. o finansach komunalnych, Dz.U. nr 19, poz. 129, ze zm.

Ustawa z 1 lipca 1958 r. o dochodach rad narodowych, Dz.U. nr 44, poz. 214, ze zm.

Ustawa z 25 listopada 1970 r. - Prawo budżetowe, Dz.U. nr 29, poz. 244, ze zm.

Ustawa z 20 lipca 1983 r. o systemie rad narodowych i samorządu terytorialnego,

Dz.U. 1988, nr 26, poz. 183, ze zm.

Ustawa z 15 listopada 1984 r. o podatku rolnym, t.j. Dz.U. 2017, poz. 1892.

Ustawa z 3 grudnia 1984 r. - Prawo budżetowe, Dz.U. nr 56, poz. 283, ze zm.

Ustawa z 8 marca 1990 r. o zmianie Konstytucji Rzeczypospolitej Polskiej, Dz.U. nr 16, poz. 94 , ze zm.

Ustawa z 8 marca 1990 r. o samorządzie gminnym, t.j. Dz.U. 2018, poz. 994, ze zm. 
Ustawa z 14 grudnia 1990 r. o dochodach gmin i zasadach ich subwencjonowania w latach 1991-1993 oraz o zmianie ustawy o samorządzie terytorialnym, Dz.U. nr 89, poz. 518 , ze zm.

Ustawa z 12 stycznia 1991 r. o podatkach i opłatach lokalnych, t.j. Dz.U. 2017, poz. 1785, ze zm.

Ustawa z 26 lipca 1991 r. o podatku dochodowym od osób fizycznych, t.j. Dz.U. 2018, poz. 200, ze zm.

Ustawa z 15 lutego 1992 r. o podatku dochodowym od osób prawnych, t.j. Dz.U. 2018, poz. 1036, ze zm.

Ustawa konstytucyjna z 17 października 1992 r. o wzajemnych stosunkach między władzą ustawodawczą i wykonawczą Rzeczypospolitej Polskiej oraz o samorządzie terytorialnym, Dz.U. nr 84, poz. 426, ze zm.

Ustawa z 10 grudnia 1993 r. o finansowaniu gmin, Dz.U 1998, nr 30, poz. 164, ze zm.

Ustawa z 8 sierpnia 1996 r. o Radzie Ministrów, t.j. Dz.U. 2012, poz. 392, ze zm.

Ustawa z 4 września 1997 r. o działach administracji rządowej, t.j. Dz.U. 2018, poz. 762, ze zm.

Ustawa z 5 czerwca 1998 r. o samorządzie powiatowym, t.j. Dz.U. 2018, poz. 995, ze zm.

Ustawa z 5 czerwca 1998 r. o samorządzie województwa, t.j. Dz.U. 2018, poz. 913, ze $\mathrm{zm}$.

Ustawa z 26 listopada 1998 r. o dochodach jednostek samorządu terytorialnego w latach 1999-2003, Dz.U. nr 150, poz. 983, ze zm.

Ustawa z 20 listopada 1998 r. o zryczałtowanym podatku dochodowym od niektórych przychodów osiąganych przez osoby fizyczne, t.j. Dz.U. 2017, poz. 2157, ze zm.

Ustawa z 15 września 2000 r. o referendum lokalnym, t.j. Dz.U. 2016, poz. 400, ze zm.

Ustawa z 30 października 2002 r. o podatku leśnym, t.j. Dz.U. 2017, poz. 1821.

Ustawa z 13 listopada 2003 r. o dochodach jednostek samorządu terytorialnego, t.j. Dz.U. 2017, poz. 1453, ze zm.

Ustawa z 24 sierpnia 2006 r. o podatku tonażowym, t.j. Dz.U. 2018, poz. 381.

Ustawa z 27 sierpnia 2009 r. o finansach publicznych, t.j. Dz.U. 2017, poz. 2077, ze zm.

Ustawa z 6 lipca 2016 r. o aktywizacji przemysłu okrętowego i przemysłów komplementarnych, t.j. Dz.U. 2018, poz. 387.

Uchwała Sejmu Rzeczypospolitej Polskiej z 30 lipca 1992 r. - Regulamin Sejmu Rzeczypospolitej Polskiej, t.j. MP 2012, nr 32, ze zm.

Rozporządzenie Prezesa Rady Ministrów z 10 stycznia 2018 r. w sprawie szczególnego zakresu działania Ministra Finansów, Dz.U. poz. 92.

\section{Dokumenty urzędowe}

Sprawozdanie z wykonania budżetu państwa za okres od 1 stycznia do 31 grudnia 2016 r., Rada Ministrów, Warszawa 2017.

Sprawozdanie z wykonania budżetu państwa za okres od 1 stycznia do 31 grudnia 2016 r. Informacja o wykonaniu budżetów jednostek samorządu terytorialnego, Rada Ministrów, Warszawa 2017. 